\title{
Distributed Energy Systems and Energy Communities Under Negotiation
}

\author{
Anna-Riikka Kojonsaari ${ }^{1}$ (D) Jenny Palm ${ }^{1}$ (iD \\ Received: 11 January 2021 / Accepted: 25 August 2021 / Published online: 15 September 2021 \\ (C) The Author(s) 2021
}

\begin{abstract}
New decentralized energy-generation technologies have turned economies of scale upside down while becoming more economically viable. At the same time, the increased penetration of information technologies has led to new opportunities to manage infrastructure in a less hierarchical, more flexible way. Together with citizen demands for control over energy, these two converging trends has put energy communities (ECs) on the agenda, potentially advancing the transition towards more sustainable energy systems, despite hindrances encountered on the way. This paper presents a case study of the planning process of a sustainable city district in Sweden, using participatory observations and interviews conducted with included stakeholders. We analyse how the included stakeholders has reasoned about establishing a sustainable energy system in the area, including a microgrid. The discussions on a microgrid comprised two parallel discourses, coexisting but seldomly explicitly confronted. The distribution system operator in the area promoted a distributed energy system (DES) solution, while the property developers opted for a microgrid organized more as a citizen energy community (CEC). We discuss why the CEC proponents so far has lost the battle of creating a community owned smart grid. We conclude that the different models, a DES and a CEC, comprise different values and an increased focus on energy communities could shift the transition pathway towards a more decentralized system involving other prioritise than just economical.
\end{abstract}

Keywords Energy planning process $\cdot$ Distributed energy systems $\cdot$ Energy community $\cdot$ Citizen energy community $\cdot$ Smart grid

\section{Introduction}

The energy system is transitioning to become more sustainable. One trend is for large-scale, centralized, and fossilfuelled systems to change to the small-scale production of renewables, with implications for the ownership and operation of energy systems [1]. Such decentralization is seen as a way to adapt the grid to better fit the needs of energy transition [2]. Decentralized renewable energy systems are being promoted by the European Union (EU). They are seen as beneficial in many ways, as they increase local energy production, bolster energy supply security, and reduce transmission losses (EU [3] of the European Parliament and of the Council, Rec. 65).

Anna-Riikka Kojonsaari

anna-riikka.kojonsaari@iiiee.lu.se

Jenny Palm

jenny.palm@iiiee.lu.se

1 The International Institute for Industrial Environmental Economics (IIIEE), Lund University, P.O. Box 196, 22100 Lund, Sweden
Decentralized energy systems (DES) also have the potential to empower and engage local communities if citizens are given control over local energy resources. Furthermore, the EU supports decentralized energy systems because they have multiple benefits, such as increased local production, energy supply security, and reduced transmission losses ([3] of the European Parliament and of the Council Rec. 65). These technical changes, with e.g. more PV and wind power, are also related to and dependent on accompanying changes in actors and institutions $[4,5]$. Another trend is for citizens to start demanding control ever energy production by establishing local community-owned renewable energy installations, such as solar power plants [6]. These community initiatives are referred to as energy communities (ECs). In this article will DESes and ECs be compared and contrasted in relation to the discussion to establish a microgrid in a city district in Sweden. The reason for the comparison is to highlight that even though they share many similarities the concepts include differences that will lead to rather different pathways depending of if a DES or a $\mathrm{EC}$ is chosen as a unit of organisaiton. Before going in more in depth to how the analysis will be done, an overview of ECs and DESes will be given Fig. 1. 


\section{Energy Community (EC)}

In the EU's "Clean Energy for all Europeans" package (CEP), citizens are in the centre [2] and great hope is put on energy communities (ECs) to make the energy system more sustainable. The CEP contains eight legislative acts, two of which are particularly important to ECs. The recast Electricity Market Directive (IEMD) covers common rules for the internal market in electricity and the the Renewable Energy Directive (REDII) established a new binding renewable target for the EU for 2030 of at least $32 \%$. Energy communities are mentioned and defined in both the RED II and the IEMD. Common for both directives is that ECs is defined as formed by the collaboration of local stakeholders who produce, consume, and manage their own energy for the primary purpose of creating economic, environmental, and social benefits for the community. There is hope that the number of ECs will increase, making them a "game changer" leading to the transition of fossil-dependent energy systems and in an increase of non-commercial actors on the electricity market. Renewable Energy communities (REC) will contribute to energy production that is increasingly local, renewable, and participatory, helping create truly sustainable energy systems encompassing all three dimensions of sustainability [7]. Citizen Energy Communities (CEC) will contribute with increasing the number of noncommercial actors Individuals can derive several benefits from being EC members, including less money spent on energy, more reliable energy supply, control over energy sources, and a feeling of participation in environmental protection, community building, and self-realization [6, 8-10]. The European Commission believes that giving citizens more control and access will enable them to improve their quality of life and finances [2]. For societies, ECs are in general said to increase renewable generation, have potential to reduce greenhouse gas emissions, mobilize private capital for renewable energy investments, improve energy system flexibility, and promote regional economies [11-14]. ECs are also expected to alleviate energy poverty and protect vulnerable citizens [2, 15]. However, the small number of ECs makes it difficult for them to contribute significantly to radical change in terms of renewable energy adoption [16]. Optimistic estimates call for half of EU citizens to produce their own energy by 2050 , accounting for $45 \%$ of the EU's entire electricity production [17]. Several barriers to such growth need to be solved, such as dependence on voluntary work, lack of resources, lack of expertise, scepticism about CEs, and lack of policy support $[9,18,19]$. Also, several barriers to EC formation need to be addressed, such as dependence on voluntary work, lack of resources, lack of expertise, scepticism about ECs, and lack of policy support $[9,18,19]$.

There is no single agreed-on definition of ECs in the literature [20], but most definitions state that they involve collaborations in local communities that produce, consume, and manage their own energy to create economic, environmental, and social benefits for the community. Walker and Devine-Wright [21] stated that an

\section{CASE STUDY OF SEGE PARK, SWEDEN}

RQ 1. How has the planning of an energy system in generaland a microgrid specifically been influenced by, if the future system has beenframed as a DES or a CEC?

RQ 2. Which conflicts have occurred and how have the actors reasoned around pros and cons with a DES and a CEC?

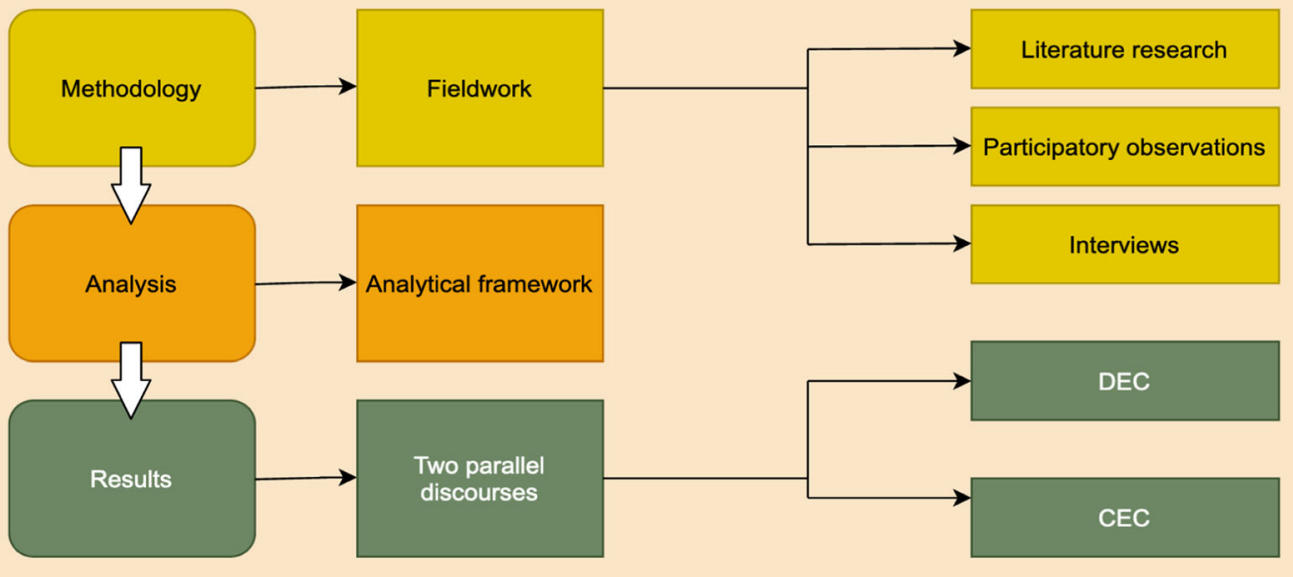

Fig. 1 Graphical abstract 
'ideal' EC project would be when a group of local people manage the project themselves and which benefits the local community. Walker [22] showed that ECs can vary depending on their location, the relationships between involved members, and whether they are virtual or physical. The literature usually describes ECs as established to produce and consume energy [23, 24], but some ECs engage in energy activities beyond production [11]. Gui and MacGill [25] claimed that ECs can also participate in activities such as transport, water supply, and waste management in order to produce social, environmental, and economic benefits for different types of communities. Studies of ECs have generally focused more on rural and remote regions than on urban areas [8].

\section{Distributed Energy System (DES)}

Another form of energy system transformation discussed in earlier research and mentioned above is to develop a DES. DES is similar to ECs promoted by the EU and the two have many similarities. DES incorporating distributed generation and microgeneration technologies such as solar photovoltaics (PVs) and is seen as beneficial because it amongs others increase local energy production and increase the security of energy supply. DES has also the potential to empower the local community, but the owners of the distribution system and technology is left undefined, i.e., the onwers could still be incumbent actors and do not need to be located in the proximity of the DES. A DES is rather defined as a system in which energy production and consumption are in close proximity (but not the ownership) [26, 27].

However, as Allan et al. [27] noted, similar to the situation with an $\mathrm{EC}$, there is no consensus in the literature as to a precise definition. According to the EU Commission [2], decentralized energy systems can contribute to the emergence of ECs and empower and engage local communities by increasing citizen control over energy resources. DESs does however not require a specific ownership or decisionmaking structure and a DES can be owned and controlled by traditional energy company or by citizens or any other constellation.

DES has become a trend due to their specific characteristics compared with those of national grids. Local communities might face new prospects in relation to the development of distributed energy systems. For example, in cities, DES' would allow consumers to trade the energy they have locally produced themselves [28].

One way towards more decentralized system is local microgeneration and local distribution of electricity by microgrids. These can be organized in different forms, as a DES or a CEC. Before the analysis of the planning of a microgrid in Malmö, Sweden, an overview of the development of microgrids will be presented.

\section{Microgrids as Ways toward Decentralization}

Microgrids have primarily been envisioned to meet the needs of remote areas due to inaccessibility of utility power, but because of the burden on the urban utility grids, microgrids focus has been shifting towards urban communities [29]. Microgrids are used in community energy systems [30]. The establishment of a microgrid has been much debated in the urban planning process in our case study that we will describe below. Microgrids are local grids that can function independently of the main grid in "island mode". Depending on the context, they can be important parts of the wider main grid, leveling demand peaks in the wider grid and helping reduce the effects of insufficient capacity. Though there are several types, a microgrid can be defined as "a group of multiple distributed generation (DG) units and loads operating as a coordinated system, connected to the main electric grid at a single point (typically, at the distribution level), and able to function in parallel with the grid or in island mode" [31]. The main characteristic of a microgrid is the ability to operate in island mode, separate from the main grid. It should be noted that connecting a microgrid to the wider grid entails challenges associated with control, protection, regulation, and customer participation [32].

Microgrids can increase the main grid's resilience [30, 33], provide increased flexibility to the operation of the power system [33] and help incorporate distributed renewable energy generation [34]. They can enhance supply reliability as they offer the potential to provide energy in case of power outages in the superordinate grid [35, 33] and sustain the supply of renewable energy even during major disruptions. Due to these reasons, they have gained popularity for resiliency enhancement). However, microgrid development is still in a formative phase [36]. Microgrids play a role in offering economic value and business opportunities in transition towards smart cities, because they facilitate interactions among stakeholders that can lead to outcomes in economic values and social welfare [33]. Furthermore, energy trading among microgrids is being developed to support energy change among microgrids [37]. Due to microgrids' resilient nature, remote microgrids are used in, for example, maritime, military, spaceship, hospital, and campus contexts [36]. According to the literature, one benefit of microgrids is increased reliability in areas where more resilience is needed, because they allow for local sitespecific generation and use of (renewable) energy. Since the scale of a microgrid is smaller than that of the main grid, less energy is lost in conversion. Due to their ability to switch to island mode, microgrids are especially useful in areas where the main grid is less extensive or where grid conditions are otherwise unreliable. The closeness of microgeneration to consumers increases the likelihood that consumers will know something about how their power was generated. Domestic microgeneration technologies such as PVs and wild turbines 
are, unlike centralized generation facilities, visible and touchable, also contributing to such awareness [38].

\section{Aim}

In this paper, we analyze the planning process of a decentralized energy systems, focusing the planning of a microgrid, in a city district in Malmö, Sweden. The analysis takes a socio-technical approach concentrating on how the included actors motivated different system designs in relation to ownership structures and values, using CEC and DES as analytical framework. Central research questions are: How has the planning of an energy system in general and a microgrid specifically been influenced by, if the future system has been framed as a DES or a CEC? Which conflicts have occurred and how have the actors reasoned around pros and cons with a DES and a CEC?

When analyzing the material in relation to DES and CES a socio-technical systems theory will be utilized to provide not only a technical but also an actor-focused approach of the planning process. Taking such a systemic approach means seeing elements of a system, such as technical components, actors and organisations and legal framework as interacting with each other in a non-linear manner. Approaching the energy system in Malmö as socio-technical means that both the material and social parts of the system need to be considered to understand the possible development paths [39-41]. This mean when analyzing the development of a microgrid, not only technical aspects, but also elements such as how the system is defined, the purpose of the system and ownership and control are essential factors for the outcome. These and other factors will be included, which is described below in the analytical framework.

\section{DES and CEC - The Analytical Framework}

To be able to analyze the two pathways we discerned by identifying and comparing differences between the definitions, purposes, and ownership structures of DESs and ECs the framework below was developed. These differences are described in Table 1, which presents the analytical framework for categorizing and understanding the dialogues and gathered empirical data on a deeper level.

DES and CEC are both characterized by distributed generation and the use of small scale energy production located in proximity to the people or technology using the electricity produced. The differences between CEC and DES is related to ownership and the purpose with the system. When it comes to DES there are no restriction in who can own and control the system, while CEC must be controlled by member not engaged in largescale commercial activity or having energy a primary area of economic activity. The purpose also differ, where an CEC opens up for more purposes than a DES. DES and CEC also comes with different values connected to them where DES is more restricted to promoting renewables and increase knowledge in the area, whereas CEC also include values such as building trust and energy literacy.

Next, the methodology will be described before the case is presented and analysed.

\section{Methodology}

In this paper, we have chosen the case study method due to its ability not only to foster understanding of specific phenomena or places but also to develop theory [42]. There is a value of case studies in generating theoretical concepts and explanations that potentially resonate in other, as yet unstudied, contexts [43]. Case studies can produce deep and concrete explanations of social phenomena and robust, trustworthy theoretical explanations [42].

The studied case is an urban development project in the Sege Park area in Malmö, southern Sweden. Although Sege Park is described as a new city district, the area has a long history. What is now called Sege Park was previously known as Östra Sjukhus ("Eastern Hospital"), the environs of a former mental hospital in northern Malmö, part of the Kirseberg ("Cherry Hill") city district. The hospital was closed in 1995. Since then, preschools and elementary schools have been established in the area and some of the buildings transformed into student residences. The goal of development projects in this city district is to transform this former hospital area into an urban area with a mix of housing, businesses, public services, and public parks. According to plans, by 2025 there should be 1340 dwellings. The development process has been characterized by a sustainable approach with a specific focus on creating a low-carbon district and innovative sharing solutions.

Furthermore, Sege Park has a Climate and Recycling Agreement and Strategy developed by the city with six goals relating to energy. This Strategy is closely connected to the goal of the city of Malmö to become the most "climate-smart" city in Sweden by 2030. The city, an energy company, and the water and sewage company all signed an agreement in January 2018 that was intended to support and facilitate property developers in Sege Park (Memory notes by Malmö city, 25 Jan 2018). Among the goals are that at least $40 \%$ of total electricity production will come from renewable sources in Sege Park, solar energy solutions should be used, and all buildings should be connected to a smart grid. 
Table 1 Analytical framework: definition, setup, purpose, and ownership structure of DES versus CEC

\begin{tabular}{|c|c|c|}
\hline Name & Distributed Energy Systems (DES) & Citizen Energy Community (CEC) \\
\hline Definition & $\begin{array}{l}\text { A system that: } \\
\text { (a) controlled by the owners who can be members or shareholders } \\
\text { that are natural persons, local authorities, municipalities, or } \\
\text { enterprises } \\
\text { (b) has for its primary purpose to generate financial profits; and } \\
\text { environmental benefits to a local area } \\
\text { (c) may engage in generation, including from renewable sources, } \\
\text { distribution, supply, consumption, aggregation, energy } \\
\text { storage, energy efficiency services or charging services for } \\
\text { electric vehicles or provide other energy services within a } \\
\text { given local geographical area }\end{array}$ & $\begin{array}{l}\text { A system that: } \\
\text { (a) is based on voluntary and open participation and is effectively } \\
\text { controlled by members or shareholders that are natural persons, } \\
\text { local authorities, including municipalities, or small enterprises; } \\
\text { (b) has for its primary purpose to provide environmental, } \\
\text { economic or social community benefits to its members or } \\
\text { shareholders or to the local areas where it operates rather than to } \\
\text { generate financial profits; and } \\
\text { (c) may engage in generation, including from renewable sources, } \\
\text { distribution, supply, consumption, aggregation, energy storage, } \\
\text { energy efficiency services or charging services for electric } \\
\text { vehicles or provide other energy services to its members or } \\
\text { shareholders; }\end{array}$ \\
\hline Purpose & $\begin{array}{l}\text { Provide financial profit for its owners and environmental benefits } \\
\text { for the local area }\end{array}$ & $\begin{array}{l}\text { Provide environmental, economic and/or social community bene- } \\
\text { fits to its members or shareholders or to local areas where it } \\
\text { operates rather than to generate financial profits }\end{array}$ \\
\hline Control & $\begin{array}{l}\text { The owners can be natural persons, municipalities, cooperation, } \\
\text { enterprises. }\end{array}$ & $\begin{array}{l}\text { Natural persons, local authorities, including municipalities, or } \\
\text { small enterprises. }\end{array}$ \\
\hline Ownership & No restrictions, can be public, private or citizens owned & $\begin{array}{l}\text { Open to to all categories of entities, as long as it is effectively } \\
\text { controlled by members or shareholders that are natural persons, } \\
\text { local authorities, including municipalities, or small enterprises. } \\
\text { The decision- making powers within a CEC should be limited to } \\
\text { those members or shareholders that are not engaged in } \\
\text { large-scale commercial activity and for which the energy sector } \\
\text { does not constitute a primary area of economic activity } \\
\text { Tied to size of shareholder and commercial activity. } \\
\text { Medium-sized-companies and companies with previous } \\
\text { large-scale activities primarily in energy generation are exclud- } \\
\text { ed (EU CEC Art 2. para 11; Art. } 2 \text { para. 8; Rec. 44) }\end{array}$ \\
\hline $\begin{array}{l}\text { System } \\
\text { solutions that } \\
\text { can be } \\
\text { included }\end{array}$ & $\begin{array}{l}\text { Produce, consume, distribute, store, and sell renewable energy } \\
\text { (heat and electricity) }\end{array}$ & $\begin{array}{l}\text { May engage in generation, including from renewable sources, } \\
\text { distribution, supply, consumption, aggregation, energy storage, } \\
\text { energy efficiency services or charging services for electric } \\
\text { vehicles or provide other energy services to its members or } \\
\text { shareholders }\end{array}$ \\
\hline Values & $\begin{array}{l}\text { Promote and facilitate the development of renewables; local } \\
\text { knowledge increase by local proximity }\end{array}$ & $\begin{array}{l}\text { A new 'non-commercial' energy market actor that can engage } \\
\text { across the electricity market } \\
\text { Electricity sharing within the CEC, build social trust in local } \\
\text { communities, revenues are kept in the local community, } \\
\text { increase in energy literacy by ownership }\end{array}$ \\
\hline
\end{tabular}

\section{Fieldwork and Data Collection}

In February 2015, the land allocation programme for Sege Park was published, clarifying that involved property developers were expected to participate in a property developer dialogue. The purpose of this dialogue was to reach agreement on strategies and procedures for testing various sustainable solutions and to design a low-carbon community. The first property developer meeting was held in May 2017. We have followed and observed these developer dialogue meetings since August 2017, and as of summer 2020, 28 meetings had been organized. For Sege Park meetings that we cannot attend, we and other participating actors have access to all relevant documentation via a folder on the Sharepoint web platform. Dialogue meetings usually last from 8.30 am to 12.00 noon, and each meeting has one or two focus themes, such as energy, the stormwater system, mobility, and waste management.

In spring 2020, 12 property developers were allocated land in the Sege Park area. At the beginning of the project, there were 13 participating developers, but one later decided to leave the project. We have interviewed representatives from all 13 developers. Property developers in Sege Park are a mixed group comprising everything from major national developers of residential housing projects to a community of private individuals who will convert one of the area's existing buildings into cooperative housing. 
Ethical considerations in this study mainly concern the anonymization of informants. It is increasingly difficult to offer full anonymity to communities or individuals in the modern world [44]. However, our aim was to anonymize informants as far as possible, so we have randomly numbered the property developers as Property Developer 1, Property Developer 2, Property Developer 3, etc., to distinguish them transparently from one another. When we have interviewed several representatives from the same organization, we distinguish them by appending letters, for example, Property Developer $3 a, 3 b$ etc. We have also interviewed representatives from the city of Malmö.

We gathered data through participatory observations, interviews, and literature research. Some interviews were conducted face to face, while others by telephone or using Zoom conference software. All interviews were recorded and transcribed. The analysed literature included three consultancy reports [45-47] commissioned for Sege Park in which the energy system is considered or is the focus of analysis. We further analysed all dialogue meeting documentation available via Sharepoint, such as PowerPoint files, notes, reports, maps, pictures, and drawings.

\section{Results}

We will start by giving an overview of our investigations concerning the establishment of a sustainable energy system in the area, where we will focus on the discussion around having a microgrid in Sege Park. We will then relate these investigations to: how microgrids are defined; their setups, purposes, and ownership structures, as presented in the above analytical framework; and the kinds of activities the DES and CEC pathways include.

\section{The Idea of a Microgrid in the Planning Process of Sege Park}

In Sege Park, the microgrid discussions concerned the installation by property owners of various sustainable measures in their buildings, such as rooftop PVs. Here we will omit discussion of the individual solutions and instead focus the analysis on the system solutions for the whole Sege Park area, especially on the discussions of a microgrid.

The first consultant report, from 2015, was written very early in the process and only listed different potential energy solutions for the area. The only energy system-related recommendation it made concerned the electricity system and establishing a smart grid. The report stated that if a smart grid and demand-response system were to be implemented in the area, a common organization running and maintaining the system should be considered. Although the report does not specifically mention the EC concept, it seems as though such cooperation was at least not ruled out. The report emphasized that if a microgrid were to be installed, it must be done in a robust way that suited people's everyday lives, which would require an organization that could support and maintain the system. However, in the report, the recommendation was not to install a microgrid, because the administrative and other costs were considered too high for such a small area as Sege Park [46].

The idea of a microgrid did not disappear from the agenda, however. Early in the process, the microgrid idea was connected to the installation of solar power in the area. The property developers saw potential in having rooftop PVs, a ground-mounted PV plant in the area, and a microgrid, making it possible to share electricity among the developers.

However, the ground-mounted PV plant needed space where it could be installed (Observation, 19 Jun 2018). One option was for the city of Malmö to allocate space in the zoning plan for PV installation in a specific green area in the middle of Sege Park, an area that the city owned and controlled. This solution was up for discussion on several occasions. At a meeting in January 2019, the city of Malmö declared that it was not prepared to have a PV plant installed in the planned greenfield area, because the PV plant would be considered a private facility benefitting the property owners, i.e., a limited number of private companies operating in Sege Park. According to the Sege Park zoning plan, any facility located in the city-owned common area needed to benefit all Malmö's citizens, not just a few actors in Sege Park. If the PV plant was a facility owned by, for example, a distributed system operator (DSO) and its production was delivered to Malmö's general electricity grid, than a ground-mounted PV plant could be an option. In this case, it would be considered a public utility with broad benefits for all Malmö citizens (Memory notes by Malmö city, 17 Jan 2019). In other words, a ground mounted $\mathrm{PV}$ plant could be installed if organised as a DES, but not if organised as a EC. At a meeting on 17th of January 2019, the DSO noted that they expected $50 \%$ of the local electricity demand to be covered by production within Sege Park, and that the other $50 \%$ could be covered by a PV park somewhere else in the region, outside both Sege Park and Malmö itself, i.e., it was not necessary for the DSO to use the green area in Sege Park (Observation, 17 January 2019). After the meeting, the property developers seemed to abandon the idea of a ground-mounted PV plant, though the idea of a microgrid survived.

$\AA \mathrm{F}$, a consultancy firm, was hired by the property developers to investigate potential energy system solutions, including a microgrid, for Sege Park. The starting point in ÅF's report for discussion of a smart grid was the establishment of PV solar production in the area. Even though a groundmounted PV plant was not an option, rooftop PVs were to be installed. ÅF stated in its report that within Sege Park, the different properties have different conditions for rooftop PV 
installation: some roofs were under conservation protection that forbade PV installation, and other roofs might have designs unsuitable for PV installation. However, the property developers wanted to use the solar energy produced in the area in all the area's properties. A microgrid would be a solution allowing buildings without PVs to be connected and benefit from the solar power produced in the area [47].

The $\AA F$ report described the advantages of a microgrid. For example, a microgrid would allow the increased self-use of PV power, which would be beneficial because the cost of buying one $\mathrm{kWh}$ of electricity exceeded the compensation received for selling an equivalent amount of electricity back to the grid. In addition, power peaks in the area could potentially be lowered, as the power use could be averaged over more consumers.

There were no technical difficulties in installing such a solution; rather, the problems related to the legal framework. According to chapter 2 of the Electricity Act, which concerns grid concessions and the regulation of exemptions from the requirement for grid concessions, an electrical distribution line must not extend between buildings. There are exceptions in the Act allowing internal networks to be built, for example, within a building or between facilities and buildings not intended as residential buildings but that are near residential buildings (e.g., bicycle parking, recycling, and laundry facilities). Certain types of properties are also exempted, such as hospitals, schools, airports, and agricultural facilities. But as the Electricity Act is written for the moment it was not possible for an CEC to own a microgrid in the area.

The report also emphasized that the development of the area was proceeding quickly and that the law was not keeping up. There was a significant possibility that the regulations would eventually change, but that a microgrid in Sege Park would be in conflict with the Swedish regulations existing at the time. For legal reasons, the consultant could therefore not recommend the construction of a microgrid connection between the properties, although the consultant was otherwise positive regarding the microgrid as a technical solution. The report said that it would be possible to prepare for a later microgrid, i.e., to lay down empty conduits (Observation, 30 January 2020). The empty conduits have been laid in the ground during 2021. A summary of how a microgrid has been discussed is seen in Fig. 2 below.

\section{Purpose and Definition of a Smart Grid}

Sege Park official documentation, strategies, and goals are written so as to support the concept of a DES. In policies and strategies such as the Climate and Recycling Agreement and the Sustainability Strategy, the energy system as defined resembles a local DES. The stated purpose of the system is that it should be $100 \%$ renewable, that it should contribute to levelling electricity demand peaks, and that it should be a smart grid, with the implicit assumption being that the system will be owned by the DSO. The system as described could be controlled by any actor as long as it fulfils the criteria set for the area; however, the Climate and Recycling Agreement for the area was made with the energy company, and this is reflected in its formulations, with the only actor specifically mentioned in the Agreement being the DSO. Also the Sustainability Strategy mentions only one actor, the DSO, when the Strategy states that the DSO should be approached for dialogue about a smart grid. The DSO is a key actor in the Sege Park area and has signed the Sege Park agreement in January 2018. It is also the actor leading the dialogue when the energy theme is discussed, or as one property developer put it:

We can choose DSO 1, DSO 2, DSO 3 [i.e., different solutions provided by the same DSO], but we may want to choose a completely different solution. (Property Developer 5)

The DSO was the actor leading the energy discussions at the dialogue meetings, giving the participants the opportunity to define the energy system and its purpose. It seemed clear that the DSO saw Sege Park as part of the wider electricity system, always discussing it in terms of how Sege Park could contribute to the whole system. At a February 2019 meeting, the DSO reflected on what kind of value a community-owned system should offer. Again, the DSO emphasized that an important value was that Sege Park was part of Malmö's electricity system, and by minimizing peak demand in Sege Park, the district would benefit Malmö's system (Observation, 17 February 2019). This comment did not lead to any discussion among the property developers. Nonetheless, the DSO had a broader system definition than did the property developers, which in general defined the system as delimited by the boundaries around Sege Park.

The property developers did not directly discuss the purpose and definition of the energy system during the meetings. They applied a more problem-based approach, discussing how to achieve the goal of achieving $100 \%$ renewable electricity supply, with solar power being the main focus. The property developers are the actors who are able to install rooftop PVs and, as mentioned above, the microgrid and directcurrent (DC) grid concepts are related to finding a way to share self-produced electricity within the area. During the interviews, many property developers expressed their desire for a shared solution in the area:

We will install solar panels in any case, but if there is a common solution, that would be interesting. (Property Developer 13)

We have looked into what we as property developers can have: a grid that property owners themselves own; 


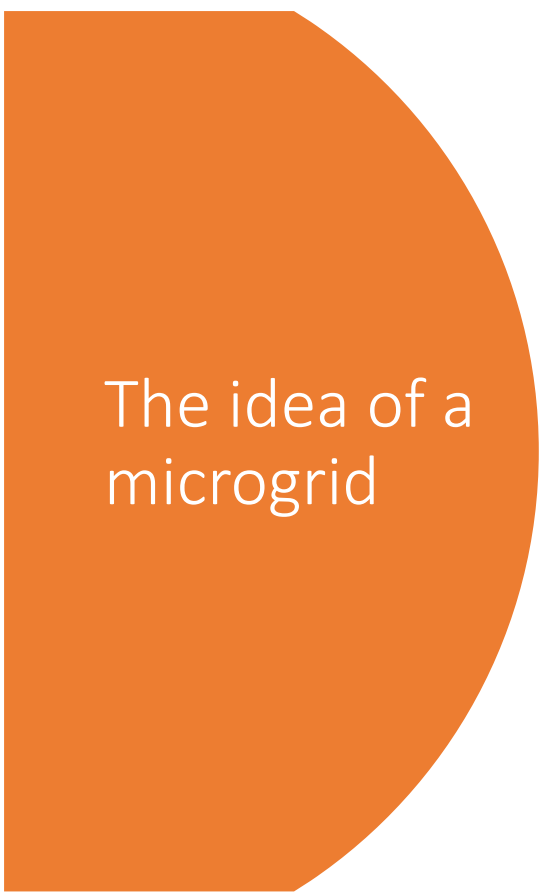

Fig. 2 The idea of the microgrid

DC so that we can keep the energy within Sege Park. Those solar panels that are planned will be connected to the existing grid, but then we have to sell back to the main grid. With DC, we could keep the energy within the district. (Property Developer 1)

We would like to look at distribution in the district between those who use electricity, but that is expensive. Sending electricity between houses would be interesting, but that is too expensive and there's not enough activity during the daytime. (Property Developer 2)

We would like to share solar energy that we produce, between us property developers and trustees. (Property Developer 3)

It was often implicit in the statements that the property owners wanted a system controlled by the residents and companies in Sege Park. The DSO's strong position was furthermore questioned by the property developers, most of whom wanted a more neutral party to lead the discussions of energy, as the following quotations illustrate:

The DSO is problematic - I am surprised that there is such a tight link between the city of Malmö and the DSO. But we [i.e., the company] have talked with other energy companies as well. (Property Developer 4a) Yes, the DSO is a powerful actor, but they are acting out of self-interest. (Property Developer 1)

It is problematic that there is a large energy player that is given a lot of latitude. It is somewhat strange that they
- First report including the idea of a smart grid

- Concluded that a smart grid is costly, but if installed, it would benefit from a

common organization running and maintaining the system

- Microgrid and solar power as combined solution in the area

- Suggestion to install ground mounted PV plant in a green area the City owned and controlled - required that the plant benefit all the city's citizens; this PV

plant would be owned by the DSO and its production would be delivered to the City grid

- Rooftop PVs were still an option with a microgrid, allowing buildings without PVs to be connected and benefit from solar power produced in the area

- No technical difficulties in installing a microgrid, but existing regulation was a barrier

- Empty conduits have been laid in the ground

- Process continues come in and set the agenda for the area. (Property Developer 12)

A discussion topic closely related to the microgrid was the possibility of using a DC grid instead of an alternating current (AC) grid. The idea of a DC grid was raised by the property developers. They noted that most appliances operate on DC, and that a DC grid would be especially beneficial in combination with rooftop PVs, which generate DC that needs to be converted to AC if an AC grid is installed. The DSO was reluctant to invest in a DC grid, stating that "it would be very expensive because it would not be an off-the-shelf solution" (Observation, 19 Jun 2018). The DSO moreover stated that a DC grid could imply the need for two parallel grids in the area, because there would also have to be $\mathrm{AC}$ in the buildings for all services to function properly. The need for two grids was confirmed by the $\AA F$ consultant, who furthermore found that the savings would be insufficient. $\AA \mathrm{F}$ calculated that a DC grid would save users $2 \%$, and that while the cost of the grid was uncertain, it would "cost a lot" (Observation, 17 Feb 2019). The ÅF report was followed by another investigation conducted by the consultant firm Knowit, which reached the same conclusion, i.e., that it was not financially justifiable to invest in a DC grid. Knowit's calculations showed that PVs in combination with a DC grid would not be financially better than having PVs in combination with an ordinary AC grid (Knowit PPt presentation, 30 January 2020).

A summary of the process in relation to purpose and definition of a microgrid is found in Fig. 3 below. 
Fig. 3 Expressed purpose and definition of a microgrid

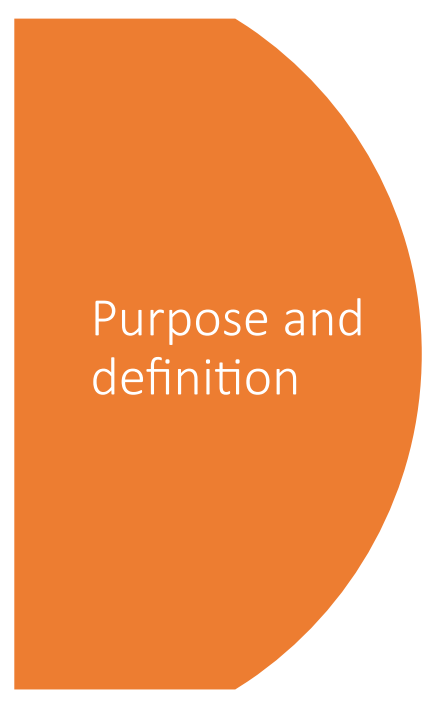

- Sege Park official documentation supported the concept of a distributed energy system (DES)

- The DSO was a key actor in the area, leading the energy related dialogues in Sege Park

- The DSO emphasized Sege Park as an important flexibility resource for Malmö's electricity system

- The property developers desired for a solution where electricity could be shared in the area

- The property developers wished for a DC, but this was considered too expensive in investigations and by the DSO

\section{Ownership and Motivation for a CEC or a DES}

In connection with Knowit's presentation at the meeting in January 2020 of its investigation results concerning the potential for a DC grid, a general discussion of establishing a local microgrid started. At a meeting a consultant who had installed a DC grid in another area in Sweden was invited by one property developer and participated via phone. When this consultant was asked for his opinion of microgrids and DC systems, it turned out that he was working with a CEC. The consultant said that CECs were important at the EU level as part of the overall energy system transition. When creating a CEC, he thought it was advisable to try to connect buildings and share PV production. However, this consultant had worked only with housing associations, which made the question of regulation unproblematic, since only single property owners were involved (Observation, 30 Jan 2020). In Sege Park, however, there are 12 property developers and connecting them in a microgrid would be illegal.

Furthermore, this consultant emphasized the need to focus on values other than economic ones when establishing an CEC: the main issue the property developers needed to clarify between themselves was whether they had an interest in jointly owning and maintaining an energy system. He emphasized that an investment in a microgrid or DC grid, or any other cooperatively owned energy system, should not be motivated by financial reasons alone, but be based on other rationales and values. The decision should be related to the possibility of controlling the system in the future, including controlling electricity consumption, distribution, and production. The decision would be a strategic one concerning what Sege Park would be like as a community. The consultant had no comment on Knowit's financial calculations, but noted that the calculations were based on today's energy system, taking no account of future developments, such as increased grid fees (Observation, 30 Jan 2020).
In the discussion that followed, the issues of ownership and the motivation for joint ownership of the energy system in the area were explicitly discussed. One property developer stated that they needed to make a decision in relation to today's system and they did not want to speculate about future costs and potential profits. His company had no interest in predicting the future, but had to rely on current facts. Another property developer agreed, stating that they could not neglect economic considerations in their decision, as all investments needed a sound financial basis. A third property developer emphasized that the investment had to contribute to an environmentally sustainable development model, and that the environmental benefits of a DC grid were unproven: considering Knowit's investigation results, it was better for the environment to optimize PV usage than to invest in a DC grid (Observation, 30 Jan 2020).

A property developer known to support a microgrid in Sege Park disagreed, stating that a DC grid would benefit the environment. With a DC grid, a lower fuse level could be used, helping lower electricity demand peaks and benefitting both the system and the environment. Another property developer was unconvinced, and responded that the DC grid would not benefit the environment, but that batteries would. The Knowit consultant interjected that the environmental value of a DC grid was low. Yet another property developer said: "I can pay for an improved environment, but I don't want to pay for anything that doesn't have any environmental value. I don't think the environmental benefits are big enough. If this is correct, then the DC grid needs to be profitable, have economical benefits" (Observation, 30 Jan 2020).

The meeting ended with mixed feelings, its being unclear whether they should proceed with a DC microgrid, an AC microgrid, or neither. When asked at the next meeting, the most pro-microgrid property developer said it seemed as if they would drop the idea. He still favoured the idea, but given the regulations, 
that time was running out, and that the electricity grid was already under construction in the area, he saw little point in continuing to drive the issue (Observation, 12 Mar 2020).

During our interviews with the property developers, some of them did assume that the property, not the DSO, owners would own the grid:

I think it would be more exciting if supplementary solutions, in addition to district heating, were tried out at a small scale by us builders. The DSO wants general solutions that they can roll out. They are not as inclined to try new things at a small scale. (Property Developer 10a)

The DSO, in contrast, assumed that it would own the grid. At one dialogue meeting, a DSO representative said: "The property owners own the electricity in their property. In the area, the grid owner owns the grid" (Observation, 19 Jun 2018).

Some property developers were more hesitant when it came to microgrids and DC solutions:

We have our property limits and must work according to contract. To think that we should try out a new way is to bite off more than we can chew. I don't think there will be many of these energy solutions - they're too visionary. We like to work slowly and in small steps and stick to the traditional process. (Property Developer 12).

Another property developer also reflected on how they seemed to end up with a traditional system and traditional energy actors:

There are quite a lot of rules that prevent us from producing as much electricity as we would have liked. They also prevent off-grid solutions. We tend to end up with traditional solutions that do not require coordination [between the builders]. (Property Developer 6).

Some property developers related the traditional solutions presented to the conservative regulations: "The laws put some obstacles in the way of development. It was also that way earlier with solar energy" (Property Developer 10b), while others believed the lack of new innovative solutions was related more purely to the DSO's central and dominant role in the process:

It is good that the DSO can showcase [what it has to offer], but not good that it is the only solution presented. There are much better solutions with geothermal heat and also if we could connect our own energy system. (Property Developer 5).
One interviewee from the city of Malmö explained the DSO's role in Sege Park but also in relation to the city in general:

The city of Malmö has sold the energy system to the DSO, and in that way we sold our control over these issues. Previously we, the city, owned an energy company but we don't anymore. Now we need to work differently by connecting the property developers and the DSO. (Representative the city of Malmö).

The city has no control or power over the DSO or the property developers, but instead needs to work through collaboration and dialogue. For the city of Malmö, the most feasible approach is to work with the DSO, which owns both the electricity grid and the district heating system, to achieve the adopted sustainability goals:

One can say that the Climate and Recycling Agreement between the city of Malmö, the DSO, and the water and sewage company are part of reaching a joint solution and acting in the same spirit. It does not help that, if we think of something, it is still the DSO that builds the system, so we also have to work preparatively with the DSO. It's about engaging them too. But they are really engaged, so it is great fun. (Representative the city of Malmö).

The discussion on ownership and motivations is summarized in Fig. 4 below.

\section{Discussion and Conclusions}

This article has presented how the idea of constructing a microgrid has been on the agenda since the start of the Sege Park project. A microgrid has been investigated more or less in depth, with the recurring conclusion that a microgrid is not an option. It has been seen as financially infeasible and as offering questionable environmental benefits. Some of the property developers have, however, disputed this and have not given up the idea of a microgrid in Sege Park. Even when they were given the message that it is not currently legally possible, not profitable, and offers no obvious environmental gains, they have kept returning to the desire to install a microgrid.

In Sege Park, the microgrid investigations and presentations have been technically oriented. Off-grid solutions are typically expensive [48], and when standardized solutions are lacking, the conclusion that a microgrid in Sege Park would be neither economically nor environmentally beneficial is unsurprising. Studying the documentation connected to Sege Park, the consultancy reports and the presentations made 
Fig. 4 Ownership of and motivations to a microgrid

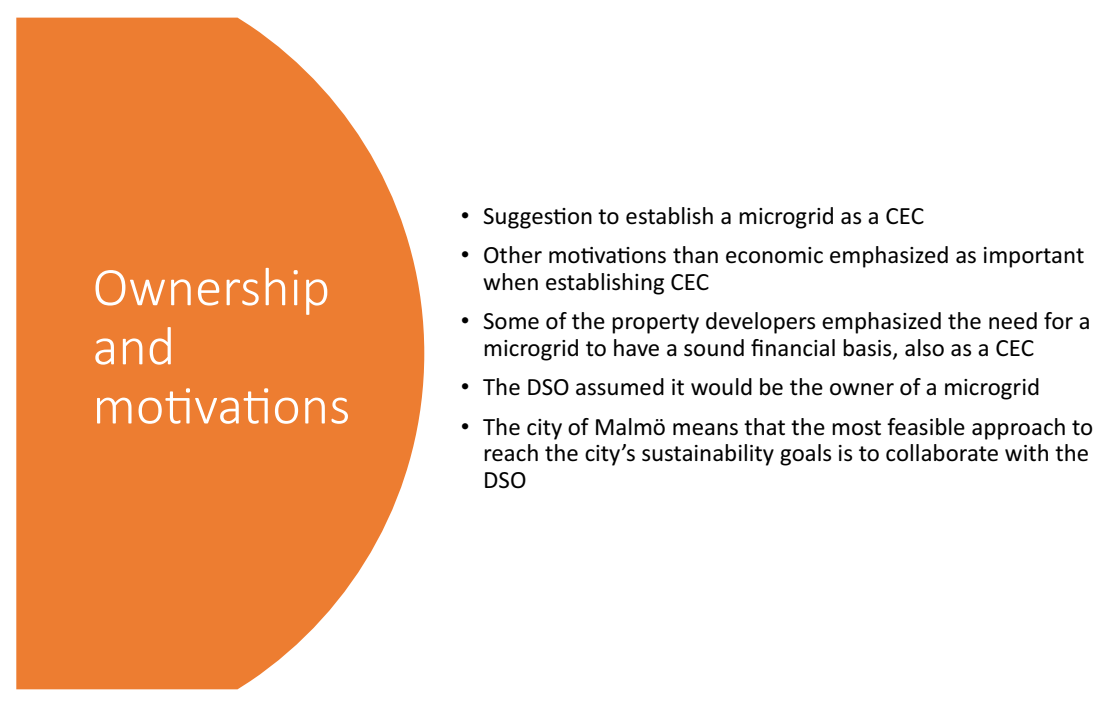

during the dialogue meetings, it seems as though the key actors are locked into centralized solutions beneficial to incumbent actors such as the DSO in this case [49]. Decentralized ownership has been put forward as an enabler of the transition towards a more renewable energy system [50,51], but there are many barriers to such change.

From a DES perspective, the transition to renewable energy systems can be made without any change in ownership. The DSO, city, and involved consultants did not consider ownership a central issue. For them, it was instead a non-issue; it is being taken for granted that Sege Park should have a centralized system owned by the DSO. This was also the pathway followed by the Swedish Energy Markets Inspectorate, when it suggested that CECs should not be allowed to own electricity grids.

The idea of developing a CEC in Sege Park was voiced by some of the property developers. They wanted to have a microgrid, owned and controlled by the property owners, for the purpose of sharing self-produced PV power between themselves.

The two pathways, as seen in Fig. 5, DES and CEC, have considerably different implications for how a microgrid in Sege Park should be assessed, differing in the systems' value, ownership, and societal contribution. If a DES is in focus, it is beneficial to install a PV system that can contribute to the city's main grid during surplus. In this scenario, Sege Park as an area is seen as an important actor helping to level demand peaks in the city's grid and helping to reduce the effects of a lack of grid capacity in certain periods. This pathway is seen more as a transition, where technological change focus on technology and economy rather than on actors [52]. From a DES perspective, it is unprofitable to install a DC grid, because such a grid cannot bear its own costs. This is also a view articulated by both the CEP and the Swedish Energy Markets Inspectorate, when it was emphasized that it is important that a CEC does not contribute to "cherry picking", where those who can afford to build their own networks and avoid paying costs related to common resources do so. In this way, the grid serves all citizens, and the EU mission of providing clean energy to all citizens can be realized (Ei R2020:02).

On the other hand, if a CEC is in focus, aspects other than just technical or economic ones are emphasized. From this perspective, local ownership by Sege Park residents has inherent values. The feeling of owning the grid together and not needing to rely on a multinational company has value in itself and will help build trust and engagement in the district. This pathway can be seen as more transformational, where the process itself as well as the outcome play a role [53]. Furthermore, several property owners saw value in knowing that they were sharing excess electricity from their PV panels directly with neighbours in the area, without going through the DSO. This has economic value because they would avoid the grid fee and could likely lower their fuse level, leading to a lower tariff. Moreover, sharing with one's neighbours has value in itself; in this transformative vision, a microgrid becomes part of building a local community, led by the actors, where residents share many things, including electricity, with one another. This transformative aspect was not considered by the DSO or the city. This led to a situation in which, when a microgrid was being investigated, values associated with engagement, the feeling of joint ownership, and being independent of the bigger grid were excluded from the analysis.

These two parallel pathways coexisted during the planning processes but confronted each other surprisingly seldom. It was first at a meeting in January 2020 that the two pathways were simultaneously in evidence. The consequences of building a DES or a CEC were not clearly articulated, however, and no real decision was made. Yet, in practice the pathway has already been chosen: the area is under construction and the DSO has connect the area to the electrical grid. The physical system will likely influence both the organization and ownership structure of the area. However, the laying of the empty 
Fig. 5 Summary of two coexisting discourses
TRANSITION

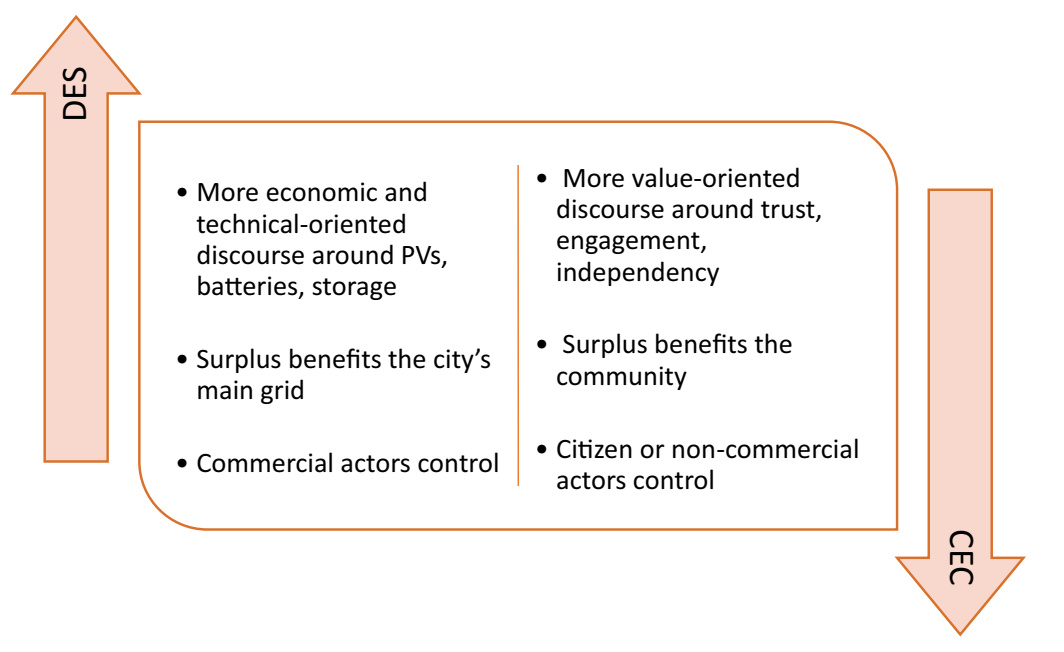

TRANSFORMATION conduits in the ground leaves the door open for a future microgrid and change in the pathway.

In this article, we have presented how dialogues around energy planning have taken place in the case of Sege Park and identified two different pathways leading to different outcomes. In both future research and future planning of local energy systems, values other than just economic and technical ones should be analysed and considered, since they play a role for the outcome. It is important to start a discussion of definitions, purposes, control mechanisms, and ownership early in the planning phase, to avoid lock-in effects and prevent the technical systems first installed when a city district is being developed from determining the possible ownership outcomes of the system. The early planning discussions should also include the aspect of values and desired outcomes. For the future, it is important to consider how to transpose the CEP ideas on ECs, including the increase of non-commercial actors on the electricity market and that profits can stay in the community.

\footnotetext{
Abbreviations $C E C$, Citizen energy community; $C E P$, "Clean Energy for all Europeans" package; $D E S$, Distributed energy system; $D G$, Distributed generation; $D S O$, Distributed system operator; $E C$, Energy community; $E U$, European Union; $M G$, Microgrid; $P V s$, Photovoltaics; $R E C$, Renewable energy communities
}

Acknowledgements An early version of this article was presented at the European Association of Social Anthropologists 16th Biennial Conference, 21 July 2020 . We wish to thank everyone who contributed to and helped to develop the article. The research has received funding from the Kamprad Family Foundation under the gran number 20182014 and the Horizon project NEWCOMERS under the grant numer 837752.

Authors' Contributions All authors contributed to the development, revision and finalization of the article. All authors read and approved the final manuscript.
Funding Open access funding provided by Lund University. This work was supported by the Kamprad Family Foundation project Resistance and Effect with grant number 20182014 and the Horizon project NEWCOMERS under grant number 837752.

Data Availability The datasets generated and/or analysed during the current study are not publicly available due to confidentiality of data but are available from the corresponding author on reasonable request.

\section{Declarations}

Ethics Approval and Consent to Participate Not applicable.

Consent for Publication Not applicable.

Conflict of Interest The authors declare that they have no known competing financial interests or personal relationships that could have appeared to influence the work reported in this paper.

\section{References}

1. Pinson P, Baroche T, Moret F, Sousa T, Sorin E, You S (2017) The emergence of consumer-centric electricity markets. Distrib Utilization 34(12):27-31

2. European Commission (2019) Clean energy for all Europeans. Publications office of the European Union https://opeuropaeu/en/ publication-detail/-/publication/b4e46873-7528-11e9-9f0501aa75ed71a1. Accessed 20 September 2020

3. European Parliament and Council of the European Union (2018) Directive (EU) 2018/2001 of the European Parliament and of the council of 11 December 2018 on the promotion of the use of energy from renewable sources, OJ L 328, 21.12.2018

4. Bolton R, Hannon M (2016) Governing sustainability transitions through business model innovation: towards a systems understanding. Res Policy 45(9):1731-1742. https://doi.org/10.1016/j.respol. 2016.05.003

5. Smith A, Voß J-P, Grin J (2010) Innovation studies and sustainability transitions: the allure of the multi-level perspective and its 
challenges. Res Policy 39(4):435-448. https://doi.org/10.1016/j. respol.2010.01.023

6. Walker G (2008) What are the barriers and incentives for community-owned means of energy production and use? Energy Policy 36(12):4401-4405. https://doi.org/10.1016/j.enpol.2008.09. 032

7. Vansintjan, D., The energy transition to energy democracy. REScoop: Antwerp, Belgium, 2015

8. Berka AL, Creamer E (2018) Taking stock of the local impacts of community owned renewable energy: a review and research agenda. Renew Sust Energ Rev 82:3400-3419. https://doi.org/10.1016/ j.rser.2017.10.050

9. Brummer V (2018) Community energy - benefits and barriers: a comparative literature review of community energy in the UK, Germany and the USA, the benefits it provides for society and the barriers it faces. Renew Sust Energ Rev 94:187-196. https://doi. org/10.1016/j.rser.2018.06.013

10. Hobson K, Hamilton J, Mayne R (2016) Monitoring and evaluation in UK low-carbon community groups: benefits, barriers and the politics of the local. Local Environ 21(1):124-136. https://doi.org/ 10.1080/13549839.2014.928814

11. Caramizaru E, Uihlein A (2020) Energy communities: an overview of energy and social innovation, EUR 30083 EN, Publications Office of the European Union, Luxembourg, 2020, ISBN 978-9276-10713-2 (online), JRC119433. https://doi.org/10.2760/180576

12. Celata F, Sanna VS (2019) A multi-dimensional assessment of the environmental and socioeconomic performance of communitybased sustainability initiatives in Europe. Reg Environ Chang 19(4):939-952. https://doi.org/10.1007/s10113-019-01493-9

13. McLaren Loring J (2007) Wind energy planning in England, Wales and Denmark: factors influencing project success. Energy Policy 35(4):2648-2660. https://doi.org/10.1016/j.enpol.2006.10.008

14. Walker G, Devine-Wright P, Hunter S, High H, Evans B (2010) Trust and community: exploring the meanings, contexts and dynamics of community renewable energy. Energy Policy 38(6): 2655-2663. Scopus. https://doi.org/10.1016/j.enpol.2009.05.055

15. Hanke F, Lowitzsch J (2020) Empowering vulnerable consumers to join renewable energy communities - towards an inclusive Design of the Clean Energy Package. Energies 13(7):1615

16. Wirth $\mathrm{S}$ (2014) Communities matter: institutional preconditions for community renewable energy. Energy Policy 70:236-246. https:// doi.org/10.1016/j.enpol.2014.03.021

17. Kampman B, Blommerde J Afman M (2016) The potential of energy citizens in the European union. CE Delft. https://www.cedelft. eu/publicatie/the potential of energy citizens in the european union/1845. Accessed 9 September 2020

18. Roberts J, Gauthier C (2019) Energy communities in the draft National Energy and climate plans: encouraging but room for improvements. REScoop. https://www.rescoop.eu/blog/necps. Accessed 1 July 2021

19. Seyfang G, Park JJ, Smith A (2013) A thousand flowers blooming? An examination of community energy in the UK. Energy Policy 61: 977-989. https://doi.org/10.1016/j.enpol.2013.06.030

20. Palm J, Eitrem Holmgren K (2020) New clean energy communities in a changing European energy system (NEWCOMERS): deliverable D3.2. Comparison of national polycentric settings in the partner countries. https://www.newcomersh2020.eu/upload/files/D3 2\%20NEWCOMERS.pdf. Accessed 1 July 2021

21. Walker G, Devine-Wright P (2008) Community renewable energy: what should it mean? Energy Policy 36(2):497-500. https://doi.org/ 10.1016/j.enpol.2007.10.019

22. Walker G (2011) The role for 'community' in carbon governance. WIREs Clim Chang 2(5):777-782. https://doi.org/10.1002/wcc. 137

23. Horstink L, Wittmayer JM, Ng K, Luz GP, Marín-González E, Gährs S, Campos I, Holstenkamp L, Oxenaar S, Brown D (2020)
Collective renewable energy prosumers and the promises of the energy union: taking stock. Energies 13(2):421. https://doi.org/10. 3390/en13020421

24. Magnusson D, Palm J (2019) Come together-the development of Swedish energy communities. Sustainability (Switzerland) 11(4)

25. Gui EM, MacGill I (2018) Typology of future clean energy communities: an exploratory structure, opportunities, and challenges. Energy Res Soc Sci 35:94-107. https://doi.org/10.1016/j.erss. 2017.10.019

26. Alanne K, Saari A (2006) Distributed energy generation and sustainable development. Renew Sust Energ Rev 10(6):539-558. https://doi.org/10.1016/j.rser.2004.11.004

27. Allan G, Eromenko I, Gilmartin M, Kockar I, McGregor P (2015) The economics of distributed energy generation: a literature review. Renew Sust Energ Rev 42:543-556. https://doi.org/10.1016/j.rser. 2014.07.064

28. Fichera A, Frasca M, Volpe R (2017) Complex networks for the integration of distributed energy systems in urban areas. Appl Energy 193(C):336-345

29. Kumar YVP, Ravikumar B (2016) Integrating renewable energy sources to an urban building in India: challenges, opportunities, and techno-economic feasibility simulation. Technol Econ Smart Grids Sust Energy 1:1. https://doi.org/10.1007/s40866-015-0001-y

30. Dincer I, \& Abu-Rayash A (2020) Chapter 5 - Community energy systems. In I. Dincer \& A. Abu-Rayash (Eds.), Energy Sustainability (pp. 101-118). Academic Press. https://doi.org/10. 1016/B978-0-12-819556-7.00005-X

31. Lo Prete C, Hobbs BF (2016) A cooperative game theoretic analysis of incentives for microgrids in regulated electricity markets. Applied Energy 169:524-541. https://doi.org/10.1016/j.apenergy. 2016.01.099

32. Yoldaș Y, Önen A, Muyeen SM, Vasilakos AV, Alan İ (2017) Enhancing smart grid with microgrids: challenges and opportunities. Renew Sust Energ Rev 72:205-214. Scopus. https://doi.org/ 10.1016/j.rser.2017.01.064

33. Warsi NA, Siddiqui AS, Kirmani S, Sarwar M (2019) Impact assessment of microgrid in smart cities: Indian perspective. Technol Econ Smart Grids Sust Energy 4(1):14. https://doi.org/10.1007/ s40866-019-0071-3

34. Kelly-Pitou KM, Ostroski A, Contino B, Grainger B, Kwasinski A, Reed G (2017) Microgrids and resilience: using a systems approach to achieve climate adaptation and mitigation goals. Electr J 30:2331 .

35. Hanna R, Ghonima M, Kleissl J, Tynan G, Victor DG (2017) Evaluating business models for microgrids: Interactions of technology and policy. Energy Policy 103:47-61. https://doi.org/10.1016/ j.enpol.2017.01.010

36. Warneryd M, Håkansson M, Karltorp K (2020) Unpacking the complexity of community microgrids: a review of institutions' roles for development of microgrids. Renew Sust Energ Rev 121: 109690. https://doi.org/10.1016/j.rser.2019.109690

37. Thakur S, Breslin JG (2018) Peer to peer energy trade among microgrids using Blockchain based distributed coalition formation method. Technol Econ Smart Grids Sust Energy 3(5). https://doi. org/10.1007/s40866-018-0044-y

38. Pierce J, Paulos E (2012) In The local energy indicator: designing for wind and solar energy systems in the home, Proceedings of the Designing Interactive Systems Conference 2012:631-634

39. Hughes TP (1983) Networks of power: electrification in Western society 1880-1930. Johns Hopkins University Press, Baltimore

40. Hughes TP (1986) The seamless web: technology, science, etcetera, etcetera. Soc Stud Sci 16:281-292

41. Palm J (2006) Development of sustainable energy systems in Swedish municipalities: a matter of path dependency and power relations. Local Environ 11(4):445-457. https://doi.org/10.1080/ 13549830600785613 
42. Baxter J (2010) Case studies in qualitative research. In: Hay I (ed) Qualitative research methods in human geography. Oxford University Press, Oxford, pp 130-146

43. Hay I (2016) Qualitative research methods in human geography, vol 4. Oxford University Press, Don Mills, Ontario

44. Dewalt K, Dewalt B, Wayland CB (1998) Participant observation. In: Russel Bernard $\mathrm{H}$ (ed) Handbook of methods in cultural anthropology. Alta Mira Press, Walnut Creek, pp 259-299

45. Knowit (2020) Likströmsnät Sege Park, Report 2020-01-27, unpublished

46. Persson A (2015) Möjligheter för DSM och smarta nät i Sege park. WSP Report 2015-02-15, unpublished

47. ÅF (2019) Energilösningar på områdesnivå inom ramen för Sege Parks Byggherredialog, report 2019-01-30, unpublished

48. Liu H, Azuatalam D, Chapman AC, Verbič G (2019) Technoeconomic feasibility assessment of grid-defection. Int J Electr Power Energy Syst 109:403-412. https://doi.org/10.1016/j.ijepes. 2019.01.045

49. Palm J (2021) Exploring limited capacity in the grid: actors, problems and solutions. Front Energy Res 9:663769. https://doi.org/10. 3389/fenrg.2021.663769
50. Haney MAB, Pollitt MG (2013) New models of public ownership in energy. Int Rev Appl Econ 27(2):174-192. https://doi.org/10. 1080/02692171.2012.734790

51. Johnstone P, Rogge KS, Kivimaa P, Fratini CF, Primmer E, Stirling A (2020) Waves of disruption in clean energy transitions: sociotechnical dimensions of system disruption in Germany and the United Kingdom. Energy Res Soc Sci 59:101287. https://doi. org/10.1016/j.erss.2019.101287

52. Hölscher K, Wittmayer JM, Loorbach D (2018) Transition versus transformation: What's the difference? Environ Innov Soc Trans 27:1-3. https://doi.org/10.1016/j.eist.2017.10.007

53. Wolfram M, Frantzeskaki N, Maschmeyer S (2016) Cities, systems and sustainability: status and perspectives of research on urban transformations. Curr Opin Environ Sustain 22:18-25. https://doi. org/10.1016/j.cosust.2017.01.014

Publisher's Note Springer Nature remains neutral with regard to jurisdictional claims in published maps and institutional affiliations. 